
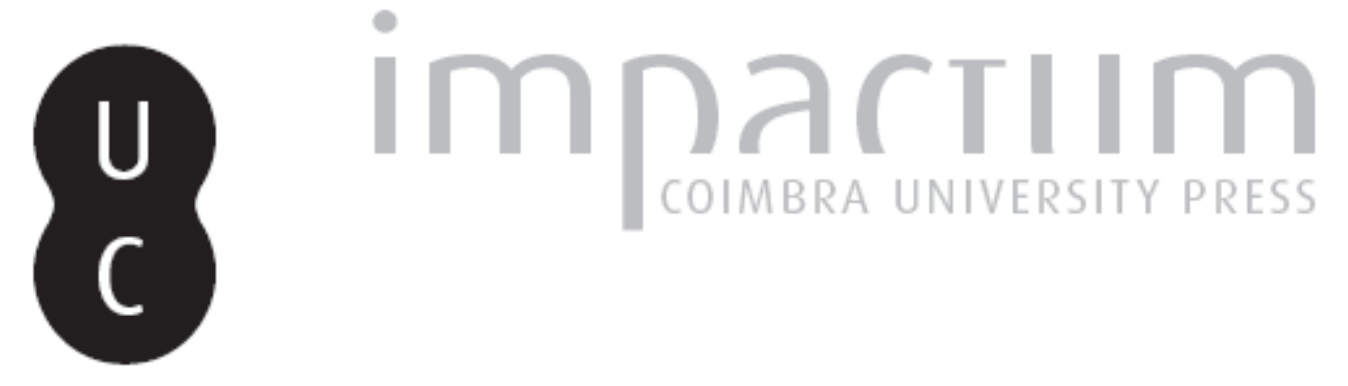

\title{
Philosophical reflections on social justice and social order in postcolonial Africa
}

Autor(es): $\quad$ Ujomu, Phipli Ogo; Olatunji, Felix

Publicado por: Universidade Católica de Petrópolis

URL persistente:

URI:http://hdl.handle.net/10316.2/33658

DOI:

DOI:http://dx.doi.org/10.14195/2175-0947_5-2_7

Accessed : $\quad$ 26-Apr-2023 12:50:07

A navegação consulta e descarregamento dos títulos inseridos nas Bibliotecas Digitais UC Digitalis, UC Pombalina e UC Impactum, pressupõem a aceitação plena e sem reservas dos Termos e Condições de Uso destas Bibliotecas Digitais, disponíveis em https://digitalis.uc.pt/pt-pt/termos.

Conforme exposto nos referidos Termos e Condições de Uso, o descarregamento de títulos de acesso restrito requer uma licença válida de autorização devendo o utilizador aceder ao(s) documento(s) a partir de um endereço de IP da instituição detentora da supramencionada licença.

Ao utilizador é apenas permitido o descarregamento para uso pessoal, pelo que o emprego do(s) título(s) descarregado(s) para outro fim, designadamente comercial, carece de autorização do respetivo autor ou editor da obra.

Na medida em que todas as obras da UC Digitalis se encontram protegidas pelo Código do Direito de Autor e Direitos Conexos e demais legislação aplicável, toda a cópia, parcial ou total, deste documento, nos casos em que é legalmente admitida, deverá conter ou fazer-se acompanhar por este aviso.

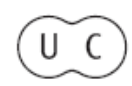



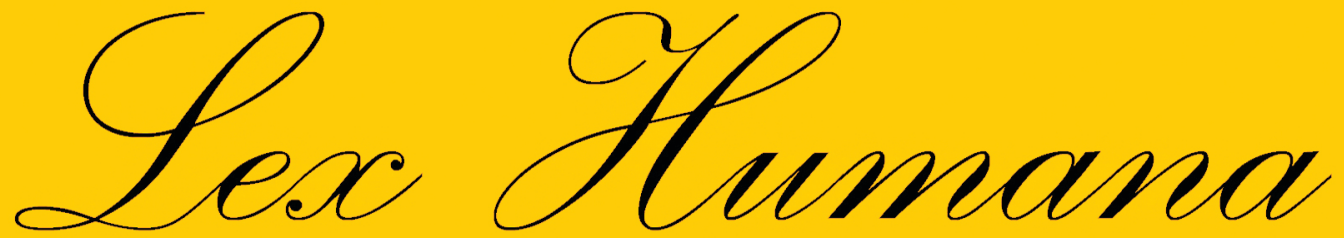

Revista do Programa de Pós-Graduação em Direito da UCP

ISSN(e) 2175-0947

Universidade Católica de Petrópolis Rua Benjamin Constant, 213 - Petrópolis - Centro CEP 25610-130

Tel: (24) 2244-4000 E-mail: lexhumana@ucp.br 


\title{
PHILOSOPHICAL REFLECTIONS ON SOCIAL JUSTICE AND SOCIAL ORDER IN POST- COLONIAL AFRICA*
}

\author{
PHILIP OGO UJOMU ** \\ UNIVERSITY OF BENIN, NIGERIA \\ FELIX OLATUNJI*** \\ UNIVERSITY OF TECHNOLOGY, NIGERIA
}

\begin{abstract}
Many countries in Africa continually face the problem of creating societies where justice will be a reality for all, most especially the teeming vulnerable and marginal peoples of the continent. Currently, the situation has deteriorated into spectral and "pervasive corruption, ineptness, authoritarianism, cavalier abuse of human rights, proclivity towards tribalistic exclusiveness" (Samatar and Samatar 2002:4) which have ensured the erosion of justice and security, and also vitiated the establishment of authentic social institutions for justice. The problem as we understand it is that the endemic susceptibility of African social and political life to injustices and perversions, is due to the absence of a proper idea of justice that can underwrite the internal consistency and wider social political consequences of the institutional developmental processes in much of Africa. Evidently, there is a compelling need to disengage from the hitherto existing idea of justice in Africa that currently, "is often a function of who you know or how much you can pay"(Harrison 2000:300). Thus, we must seek a more systematic and holistic way of creating and institutionalizing the principles and values that can ensure enduring and viable social justice that can in turn positively affect the redirection of African social order and development towards security, morality, peace and well-being.
\end{abstract}

Keywords: Social justice; social order; post-colonial Africa.

\footnotetext{
* Artigo recebido em 27/08/2013 e aprovado para publicação pelo Conselho Editorial em 10/12/2013.

** Dept of Philosophy and Religions, Faculty of Arts, University of Benin, Benin-City, Nigeria, e-mail address: pujomu@yahoo.com, Phone Nos.+234-803-380-6804,+234-807-770-7735 (Lead Author.

** Dept of General Studies (Philosophy Unit), Ladoke Akintola University of Technology, Ogbomoso, Nigeria, email address: felixolatunji28@gmail.com, Phone No.+234-802-749-4860.
} 


\section{Introduction and Problem}

As things stand, there is a spectral deficit in the postulation of a modern idea of social justice that can defend or enhance the imperative of a social political development for many societies of Africa. This fact is significant, because most African social orders are defeated by a dual tragedy of the inapplicability of their indigenous ideas of justice to modern social challenges and the pursuit of development in Africa. In the post-colonial setting, the rule of justice is obstructed by negative ethnicity, corruption, disobedience to law and order, disdain for the rule of law and accountability and the disregard for the value of human life and the common good.

The problem of creating African societies where justice will be a reality for all, especially the vulnerable and marginal peoples, is currently a priority concern when, seen in the context of the deterioration of many African societies into spectral and "pervasive corruption, ineptness, authoritarianism, cavalier abuse of human rights, proclivity towards tribalistic exclusiveness" (Samatar and Samatar 2002:4). Such tendencies have ensured the erosion of justice and security, and also vitiated the establishment of an authentic philosophy of development. This crisis is explained by the fact that even in recent times, most African societies have failed to overcome the fundamental injustice arising from their primordial and colonial natures. The fact is that "the contemporary African state is an instrument of colonialism, that, when abandoned by its creators, was picked up with gusto by the new political elites" (Pham 2005: 41-42). For some writers, the crisis of justice in the modern African states predates the colonial heritage. The question then is: how did Africans get to this stage in the problems bedeviling them? This is historical question that draws attention to the interplay of cultural choices and phenomenological possibilities. Only a sustained and systematic analysis of the justice component and its linkages to the foundational but wider social experiences can shed light on this problematic.

In looking at the African conceptions of justice, we must not fail to remember that "at certain stages of material civilisation, our choice of a distributive principle depends on the consideration given to social values other than justice" (Eshete 1975:38). This means that the issue of justice must be seen against the back-drop of wider social realities. In insisting on the question of social values there is a concern for the intricacies of the cultural operations that underlie social principles and the institutions that are meant to carry them through. With special reference to justice, we are interested in discovering the consistency, viability and approbation derivable from the notions of justice embedded in African cosmologies. In a way, a good point of entry into our study is to assume that "justice is satisfied if each person can recognize that 
the institution is designed to work to his advantage- or at least not to his disadvantage- in the long run" (Fried, 1964:239). If this is the case, we must then try to discover whether, taken together, the endogenous African and exogenous ideas and contexts of justice have apparently not worked to the advantage of the Africans over the ages. If these have worked well, then why do we still have developmental shortfalls that need a new form or philosophy of justice for development? And if they have not worked, how and why were these defective justice systems installed and sustained? By what means can we rectify the adverse effects unleashed by these worrisome categories? These are the kinds of ethical, meta-ethical and epistemological issues that confront us in this essay.

The Value of Justice or Justice as a Value: A Theoretical Framework for a Philosophy of Justice for Development

The quest for an alternative view of justice that can ensure the liberation and transformation of Africa must apparently depend on a combination of principles and values that will form the composite for rectification. We must confront the critical problem of devising a sustainable strategy for normative change and social or cosmological reconstruction that is embedded in the recreating of a philosophy of justice for development. What are the means for the improvement of the African situation vis-a-vis the quest for an idea of justice for development? Firstly, there is the compelling need to disengage from the hitherto existing philosophy of justice in Africa that currently, "is often a function of who you know or how much you can pay"(Harrison, 2000:300). This requires a repudiation of forms of debased and unwholesome conduct in the justice arena.

In most parts of Africa, we can easily calibrate the scope of the failures of the various instruments of justice, such as the police, national assembly, appointed ministers, law courts, prisons, etc. the operations of these institutions have been defeated largely by inefficiency, under-funding, incompetence, ethnicity, politicisation and social dissatisfaction. As Fox (2000) observes "any account of what the courts are intended to achieve immediately shows up their inadequacies and deficiencies." Thus we must seek a more systematic and holistic way of creating and institutionalising the principles and values that can ensure enduring and viable philosophy of justice that can positively affect the redirection of African development towards security, morality, peace and well being. This is a normative and empirical engagement with the African historical and cultural values. To succeed, our effort depends on a dualistic moral and institutional re-entry into reconfiguring the African problem of social change for liberation and transformation. In concrete terms, we argue for an idea of individual futuristic justice embodied 
in the concept of trust that depends on the distributive paradigm understood as that, which takes from each according to his ability and gives to each according to his need or contribution.

Let us now descend from the meta-ethical realm to the engagement with existential and phenomenological realities. The first stage of the theorising for rectification is to seek certain existent principles or derivable templates for erecting a new or alternate view of justice. This task requires nothing other than the erection or recalibration of core values for a new philosophy of justice for development. A progressive or viable society is likely to define justice or "distributive justice as that which also interests of future generations" (Grondona, 2000:48). Luckily, the Africans had, and still do have a concept of this consideration for the future and even for the past or dead people. This advantage can be turned to the side of the Africans in their search for an alternate form of justice. Mbiti (1969:105-107) puts it to us that the African kinship system "extends vertically to include the departed and those yet to be born. African concept of the family also includes the unborn members who are still in the loins of the living." The next thing, therefore, is to employ the substrate provided by this philosophy of consideration for generating a stable and just system for African societies that judges or reckons with posterity.

Given the problematic as we understand it, the endemic susceptibility of African social and political life to injustices and perversions, is due to the absence of a proper idea of justice that can under-write the internal consistency and wider social political consequences of the developmental processes in Africa. But then "to talk about injustice requires the use of moral concepts and the making of moral judgements" (Crocker, 1991:460), thus implying that we are in need of core normative, ethical and phenomenological presuppositions that can foster certain developmentally suitable values and attitudes. In our search for a viable philosophy of justice in Africa "principles of justice are needed, because not all demands and claims can be satisfied; principles of justice are the answer to inevitable disappointments and inequalities" (Ehman, 1980:14). However, the attainment of this end necessitates the postulation of a new philosophy of justice for viable social order and holistic development in Africa.

\section{Modern Africa, Development and the Challenge of Establishing a System of Social Justice}

We may reiterate the point that every state is known by the nature and quality of justice that it maintains. The sort of justice that modern Africa requires for its development is a system of social justice, which aims at a pattern of fair treatment for people. The primary subject of 
this justice is the way in which the major social institutions distribute fundamental rights, duties and determine the division of advantages from social co-operation. Justice has to be defined according to certain principles of equitable, fair and humane distribution of benefits and burdens. Justice makes sense as the attempt to reconcile opposing views and desires, and the intention to work out a free, fair, beneficial and equitable means of producing and sharing social goods. Nielsen (1996:82) puts it that "the question of justice is the question of what is that genuine social order that can guarantee human flourishing (and) social harmony in which people acknowledge their communal nature and their self-autonomy" (Nielsen, 1996:81-82).

Conceived in this manner, justice is a concept operational in the domain of the joint claims and actions of persons. Justice refers to that respect which persons show for "the freedom of others, and the chance that they give others to be themselves, and to develop their potentials". (Peperzak, 1971:154-155). It affirms the sociality of man and the immense importance of providing "a reasonable basis of agreement among people who seek to take due account of the interests of all" (Nielsen, 1996:86-87). The need for social transformation and rectification compels an interrogation of the core principles of social order as they affect those groups that are susceptible to injustice. This raises issues about the reconstruction of just social order. Viable social order operates on at least four central principles. They are the ideas of common good, personality, solidarity and subsidiarity. The first principle is that of the common good John Paul II, Laborem Exercens 1981:68, Werhahn, 1990:28, Neuner and Dupuis, 1990:720). Brugger (1972:62-63) holds that this principle affirms that state's duty to ensure common justice and fairness in the relationship between individuals.

To the extent that there is a need for the conscious and systematic institutionalisation of the mutual bond in the society, then the actualisation of the common good becomes a moral concern. And as such becomes a basis for the attainment of justice and other core values. The point made by St. Thomas (1990:51-52) is significant here. He holds that social justice directs human actions to the common good. Therefore, Mill (1990:302 - 303) holds that justice arises from the fact of living in the society, and it renders it indispensable that each man should be bound to observe a certain line of conduct towards the rest. In this case, it requires that individuals must recognize the personhood of others and their rights to have a secure and worthwhile existence. The application of the rules of justice ensures that man can live with dignity, freedom and responsibility. Freedom as one major essence of human life is to be upheld because without it, man cannot develop. This point is most significant in relation to those in governance and the governed. 
According to Kymlicka (1999:6), a theory of justice in a multi-cultural state will combine universal rights with group-differentiated rights. For Kymlicka (1999:187), the possible basis of social unity in a multination state cannot be far from the retention of feelings of social or national consciousness, commitment and a strong sense of patriotism. In a way, social unity depends on shared values. Such values may include: belief in equality and fairness, belief in consultation and dialogue, the importance of accommodation and tolerance, support for diversity, compassion and generosity commitment to freedom, peace and non-violent change. Thus, Nielsen (1996:81) has stated that "a just social order cannot allow a society of slaves where for some people, resources external to them are properly subject entirely to communal control, such that they, having no control or very little control of the means of life have their autonomy undermined". Given the above situation, Pojman (1997:549-558) is right when he insists that "justice is a constant and perpetual will to give every man his due". A society that has a commitment to rewarding those who contribute to its well being and punishing those who purposefully undermine it will survive and prosper better than a society that lacks these beliefs or practices. Evidently, the proper question of justice is the calibration of a system of institutions, practices, values and beliefs. It is the whole gamut of the reorientation and transformation of ways of life.

Still on the normative and phenomenological conditions for the erection of justice in Africa, we can also learn from Hospers (1976:616) that a just society needs to "define and recognise individual rights and to embed these rights in the constitutional structure, so that no would be tyrant can take them away". More importantly, it should be noted that the specific function of justice is to establish between these claims, the due limits and harmonious proportions (Johann, 1966:41). Hence, we can rightly say that justice refers to the respect that a person shows for the freedom of the other, the chance she offers the other to be what he is, and to develop his possibilities in this world (Peperzak, 1971:355). Against this bac-kdrop, we can better appreciate the view of Pazhayampallil (1995:876) that justice is the fundamental principle of the existence and the coexistence of man as well as of human communities, societies and peoples. It is right for Haring (1979:470) to say that justice needs to be upheld in order to ensure that there is peace, order and stability in the society. The consistency and commitment with which a society seeks peace will determine the extent to which it will guarantee the survival well being of the people.

Individual Responsibilities and Social Commitments for Sustaining a Just Society

According to Nielsen (1996:85), social justice deals with how social institutions are to be arranged, as well as, how just social institutions can be established. Nielsen argues that an 
understanding of the meaning of a just society facilitates the understanding of the interconnection between individual responsibilities and mutual expectations. However, Young (1990: 15-16) maintains that the central concern of social justice is to eliminate institutionalised domination and oppression. To this extent, the idea of social justice encapsulates every aspect of institutional rules and relations, which are subject to potential collective decision. In the light of the prevalence of social conflicts, question about social justice will continue to be relevant, in so far as there is domination and oppression in society. It is obvious that social justice emphasises the well-being and welfare of every individual in society. Social justice is, therefore, a fundamental framework for the total development of the human person in his or her physical, social and spiritual life.

Social justice among other things demands the establishment of institutions and rules of fair competition for social benefits and the equality of opportunity for every individual or group to develop his or her capabilities and talents to the optimum. It seeks to create those economic, political, moral and intellectual conditions, which will allow the citizens to live a fully human life" (Pazhayampallil, 1995: 878-879). Thus, the institution of social justice is indispensable for the establishment and sustenance of social order, because it provides the basic principles and structures by which we can achieve just distribution of benefits and burdens in the society. The establishment of a system of social justice is of immense importance, especially to the multiethnic nation-states of Africa. The requirements of social justice in these ethno-cultural plural nation-states demand the urgent establishment of an open society (Gyekye, 1997:89). Such a society must be a democratic system that gives fair and equal consideration to the interests of all citizens, irrespective of their creed, sex and background. In such societies, merit and achievement must be given pre-eminence as the critical conditions for the distribution of honours and benefits. What institutions can promote the conception of justice that we are recommending?

Social justice among other things demands the establishment of institutions and rules of fair competition for social benefits and the equality of opportunity for every individual or group to develop his or her capabilities and talents to the optimum. We reiterate that the establishment of a system of social and effective justice is of immense importance, especially to the multiethnic nation-states of Africa. In the context of Africa, therefore, "the central core of the idea of justice is the exclusion of arbitrariness and more particularly the exclusion of arbitrary power" (Ginsberg, 1963:109). If this repudiation of arbitrariness is an imperative, and if really, we cannot escape from the current quagmires occasioned by a miasma of invidious cosmological traditionalism and foreign-induced post-colonialism in the African justice agenda, then, we must 
face a conception of justice that is not "blind to particular subjects. Quite the contrary, it looks to those who stand before her and demands from us the response, which is appropriate for them" (Carr 1981:224). The crucial question then is; is it possible to have "a social order built around a particular notion of merit" (Daniels 1978:206)?

What, if any, are the practical action-intervention strategies of our sustained theorizing on justice for development in Africa? It is important to note that the institution of justice operative within the humane and viable social order must proceed beyond the guarantee of fair competition and the equality of opportunities, as the rules of social interaction. In addition, the social order must give adequate consideration to the fulfillment of the social and economic needs of the people. In other words, there must be a conscious attempt within the society to reduce social and economic deprivation among the generality of the people so as to guarantee the greater peace and stability of the African social orders. Given the fact that there can be no stable social order in a society where the economic situation of the majority of the citizens are dismal and restrictive, then the alternate social order postulated for Africa's development has an important task of alleviating the economic inadequacies of its citizens. In this regard, it makes little sense to uphold the formal equality of political rights, when there are widespread economic inequalities and social disempowerment.

Hence, it should be emphasised that genuine and enduring justice cannot be realised in its true form, unless those critical issues bordering on economic administration and distributions are taken into consideration. It is true then that justice is at the heart of "determining what constitutes the human good. Justice would then have to be what a governing power ought to command with a view to the realization of the good of the citizens. However, a controlling power can hardly by itself secure the well-being of the citizens. A large part of the well-being of individuals can only be secured by their own efforts" (Mackenzie, 1963:155). This means that we must seek justice for Africa in a type of social order that allows individuals to choose and appreciate the things that are of value to them. Such a conception must repudiate the tripartite defective traditionalist, western and modern African views of justice in their perverted forms. Definitely, an acceptable philosophy of justice for Africa must clearly have as its directing principle what Young (1990:15) rightly says is "the elimination of institutionalised domination and oppression", which manifests in a plethora of ways in the endemic educational lapses, dismal unemployment, cruel marginalisation of minorities, elite corruption and profligacy, the ascendancy of poverty and the entrenchment of lawlessness, insecurity and anomie. The truth is that a lot of these occurrences are unnecessary and unacceptable given the resources (human, natural and financial) available to most African nations. Also, we begin to be strident in our call 
when we come to the vital realisation that social transformation and normative rectification have become imperatives of African destiny and survival in the global arena.

Key Institutions and Values Necessary for the Establishment and Sustenance of Justice in Africa

Against the background of the crisis of justice and the social order in many African nations, there is need to discuss some of the key structures and institutions that we need to create in order to establish viable and sustainable social order in these nations. Every society requires certain structures and institutions in order to maintain or achieve some level of wellbeing, stability and progress. In fact, the well-being of a society and its capacity to meet the challenges of human existence, are determined by the strength and efficacy of its social, political, economic, educational, legal, cultural and religious institutions. However, it should be noted that the members of a society cannot achieve the peace, security and progress of each and all, unless they establish a clear and effective system of social justice. In fact, the fundamental questions of political morality or the proper relationship between individuals, groups and agencies within the state will not be fully and adequately resolved unless a mutually agreed system or principle of social justice is installed in the society.

To foster a new idea of justice, we must come to terms with certain truths. One truth is that there are already some institutions in Africa. Some inherited from the colonialist and others emanating from our traditional past. The time has come to expunge the bad institutions local or foreign and then to adopt new institutions that can facilitate the requisite change that is urgently needed. One of the modern institutions necessary for the establishment of just social order is the Constitution. It is crucial for the establishment of social order for the following reasons. Every viable and just social order requires a legal and authoritative document, which spells out the basis of, and rules guiding all social activities. It outlines the fundamental principles and laws that are to guide the administration of national life. It is, therefore, the expression of the fundamental agreement of the society on the way individuals, groups and the society are to be governed. It is a statement about how the burdens and benefits of social co-operation and concessions are to be determined. Also, the Constitution establishes social order by defining or better still, limiting the authority and power of government, leaving to it that which is minimally required to be effective in pursuing the common good without stultifying the well-being of any group or the society. It emphasises the separation of powers and ensures that political authority is restrained by a system of checks and balances. By so doing, it reduces the fear and possibility of arbitrary and absolute power being concentrated in the hands of any one person or group. Thus, the constitution stresses the importance of rights, individual freedom and devolution of authority for the sustenance of social order. 
The need for a constitution arises because there should be a generally accepted system of social interaction, which will guide the harmonisation of the diverse interests of competing groups in a society. The constitution seeks to define what is right or proper by creating a system of laws based on the demands of justice and freedom. It is thus construed as the positive political morality of a nation, which ensures the obedience of the citizens to moral principles. It should, however, be noted that the constitution in itself, no matter how well written, cannot by itself establish viable social order. Rather, it requires the active participation of those human beings who will uphold, and live out its dictates. Therefore, there is a link between the constitution, good government or leadership, and the society. The institution of leadership is of crucial importance to the sustenance of social order.

Many nations in Africa suffer a crisis of justice and social order due to the effects of bad and inept leadership arising from warped conception of power. This fact under-scores the importance of purposeful leadership for good democratic governance and the maintenance of viable social order. The kind of leadership required for the establishment and sustenance of a stable and productive social order is one, which exhibits foresight, vision, a clear sense of purpose and charisma. Such qualities of good leadership are important in the efforts to establish a social order that is peaceful, secure and human. Also, such leadership will serve as the nucleus, which motivates, directs and controls the social, economic and political activities of the society. More importantly, the kind of leadership, which is relevant to the establishment of a viable social order, must be one that is based on the free choice of the citizens.

There must be a free and fair choice of leaders and administrators in a genuine social order. This fact demonstrates the significance of democracy as a major instrument for the establishment of social order. Democracy entails the free and voluntary choice of leaders who have been elected in a peaceful and organised manner, to manage the affairs of the society. The democratic procedure of choosing these leaders endows them with the legitimacy and sovereignty to rule on behalf of the members of the society. Furthermore, good leadership is demonstrated through good governance, which is itself very important for the sustenance of social order because it demands accountability of officials for public funds. It also demands transparency in government procedures and decisions. It demands predictability through rational governmental action. And it demands openness, so that there can be free and reliable flow of information necessary for economic and social activity. Furthermore, good governance as a mark of purposeful and humane leadership demands the establishment of an independent judiciary, a free press and an efficient public service. It also demands the establishment of a pluralistic institutional structure and the respect for the law and human rights. 
However, it can be argued that even if leadership is a necessary condition for social order and social transformation, it is not a sufficient condition. In other words, no matter the good intentions, humaneness and purposefulness of a leadership, it will not be able to establish justice and social order except core social and humane vision and values become institutionalised in the society. How then can the core social values and visions be institutionalized in the society? There are two major ways through which core values and visions of justice and humaneness can be institutionalised. The first way is through the use of formal institutions or arrangements of political power and administration. The second way or method of institutionalising social values and visions is thought the use of informal institutions. Furthermore, the visions and values can be institutionalised through the use of informal arrangements such as political parties, professional bodies, voluntary associations, the media, youth movements and traditional leadership structures. The combined forces of these social segments must return to the fundamental ways and imperatives of effort, industry, conscientiousness and general application of themselves to the works of creativity, intelligence and innovation if justice is to prevail across Africa. What kinds of tasks confront the institutions and structures directed at attaining justice in Africa? We can identify some major axiological and legislative commitments of these core social institutions and then present their task in a more theoretical manner. These structures and institutions that can be identified and discussed must be put in the "service of human dignity" (Lasswell 1956:90) understood in its widest sense as the creation of opportunities for well being, self respect, progress and civilised conduct among men.

\section{Power Structures and the Establishment of Justice in Africa}

Burns (1981:5) states that "the toughest and most central question in American politics and political science is the question of power." The same is applicable to Africa. It is clear from current happenings that the whole question of power and its management can be said to be central to the question of justice in Africa. We are talking about political power here, which seems to yield other kinds of power in Africa. The traditional view of power refers to the "ability to get another actor to do what it would not otherwise have done" (Goldstein, 1999:55). While we do not have any grouse with this conception of power, we are more interested in the idea of power as a value. To this effect, "participation in the making of decisions (power) is a value. We are interested in the interrelation of power with personality and the whole social process" (Lasswell, 1956:93). Furthermore, we are concerned about the way by which a person or group 
with power can be made to act justly or see the need for doing so. If this is so, then we are interested in how power can be negotiated or made to serve the interest of higher and positive values or goals. In this sense, we are interested in the idea of "power as domination, as the ability to control or command" (Litke 1992: 176). There is a profound connection between power and justice. As Morgenthau (1974) puts it, “the object of somebody's power opposes that status in the name of justice, and the holder of power justifies it, also in the name of justice. The real issue arises between power and its victim or between power and power, each claiming justice for its cause" (Morgenthau 1794: 163\&166). This turbulent aspect of power is undoubtedly one of the greatest challenges facing Africans in their quest for justice. The factor of human nature and the critical possibilities for perversion that arise from the real challenge of a negative use of power in Africa, must be situated against the backdrop of the reality of conflicts and imbalances that power relations either serve to exacerbate or mitigate. According to Soyinka in A Climate of Fear, Lecture2: Power and Freedom, 2004, the factor of power is "a motivating component of human personality. It is the ancestral adversary of human freedom", seeking to control and dominate the other. Most personalities and institutions that have been vectors of power in Africa have persistently surrendered to domination, authoritarianism and even outright tyranny and despotism. The theme of domination has been emphasised as one of the most popular extremes of the exercise of power. According to Partridge (1963: 118), "it is a defining characteristic of the situation that the one man is compelled to surrender his own desires or interests, to yield without any compensation to those of the power- holder." Such a crisis-ridden conception of power inevitably throws up a regime of turbulence. We must seek to develop an alternative conception of power as directed towards service to the other or society. The psychological, cultural and institutional underpinning of these problems cannot be overemphasized. Young (1994:88) has noted that given the fact of the corruptive tendencies reposed in power "one of the secrets of a good society is that power should always be open to criticism." In fact, the crux of the negotiation with power is to "moderate the power of the rulers over the ruled" (Scott, 1992:122).

The question of the extent to which human nature is altered by deprivations and dehumanisation becomes important, given the increase in the tendency to abuse power even when there is no evident need for it, or perhaps, when the circumstances seem inauspicious. The immanent loss of control in the face of the temptations of power, are quite unprecedented. Put practically, the inordinate lust to dominate, defy others (persons, institutions and ideas) remains pronounced in Africa and compels a reconstructive analysis of the concept. This is significant when we realise that core institutions such as education may not have fully mitigated 
these negative propensities in people. In so far as power is connected to capabilities, then we must establish the minimum fact that power must be subservient to moderation through institutional checks and balances, educational formation, that will hopefully, prevent arrogance, failure, oppression and injustices that really seem to be overwhelming a number of African societies.

Unfortunately, the state-centrism of most African societies has made the bulk of the people too dependent on the state, and therefore on whoever controls the machinery of the state. In many cases, such persons have exhibited some of the worst tendencies in human nature. They have represented the worst that Africa can produce. This situation has raised further questions about the ways by which choices can be made as to who will be allowed access to power. Presently, in many parts of Africa, power seems to be circulating among the old, redundant and corrupt elites, who have continually failed their different peoples and societies. The mismanagement of power has led to some of the most protracted conflicts and endemic injustices in the history of modern Africa. Let us recall the different contexts, and consequences of the mismanagement of power in Nigeria, Somalia, Sudan, Liberia, Zaire, Central Africa Republic, at various times in the histories of those countries. Where state centrism works one any have no serious objections to its practice. But has it really ever worked? Where it does not work, then, the critical failings of the system come into full glare. In addition to its many shortcomings, state centrism evidently, does not permit the free exercise of human genius, the blossoming of subsidiary institutions. In short, we can agree with Mackenzie (1963:155) who says that "a little reflection, however, suffices to show that a controlling power can hardly by itself secure the well being of the citizens. A large part of the well being of individuals can only be secured by their own efforts."

Thence, there is a need to create alternative structures for decentralising and countervailing the power consolidating institutions in Africa. To this effect, the role of the civil society groups, political parties, legislative bodies, organised trade unions and other interest groups, where properly organised and uncorrupted, can be useful. But we are faced with the fundamental question of the rules and processes of their formation, and the question of whether their goals are directed at some specific end or for that matter, the realisation of the common good. A vital issue, however, is the expediency or otherwise of forming and sustaining such groups. Experience seems to suggest that rights and justice claims are taken more seriously in Africa, if these are articulated and pursued under the platform of groups, whether artificial or primordial. Pritchard draws our attention to a wider conception of political power that goes beyond "the ability to make and enforce decisions about matters of social and political 
importance" ... to the whole question of political influence or "the ability to prevent matters from becoming objects of decision in the first place" (1979:26). In the case of power in Africa, there is a need to work out sustained strategies for ensuring that only credible and moral persons do have access to, and use of power at the most important levels. Such efforts will impact on the redefinition of values and value systems and value frameworks, understood as the things that (should) interest us, the socially possible and accepted ways of achieving these objects of interest, and the kinds of institutions that can facilitate or hinder the attainment of these interests.

Furthermore, the philosophically challenging issues arising from the above analysis remain crucial to the question of the nexus between power, control and responsibility. Said (1977:38) makes the point that "power becomes destructive only when committed to the service of a narrow conception of morality. Power can be used for moral or immoral purposes." Anyone can actually retain power; even common criminals exercise power, howbeit, cruelly and fleetingly. We also know that power gives rise to a sense of security. But power in itself, and the security that comes from it, are both equally ephemeral when such are not founded on a strong moral or social authority, and the desire to employ such for good. Whereas power embodies so much capacity to control, yet it must bring itself to bear on the crucial issue of responsibility. The questions of accountability, liability and responsiveness are integral elements of the definition of a more viable conception of power and the control that goes with it. It has been said that "power and accountability are not antithetical" (Whitman, 2002:51). We can ask whether the exercise of responsible power is a prevalent feature in Africa. The question of power is undoubtedly tied to ideology and its outcomes. Justice in Africa, which requires a renegotiation of the power issue, is all the more important, when we note that "the social cooperation and coordination of human activities, which is the essence of civilised life, is not possible without regulation" (Harris, 1957:1). Such regulation can only come from a negotiated, humane and progressive conception of power directed at the common good. Dialogue is an instrument for deciding on the locus and focus of power in a highly volatile African environment. The kind of power that is required is one that takes decisive action against nonprogressive, unwarranted and unjustifiable "segregation and discrimination" (Glazer, 1981:13). Dialogue as a Basis for Justice and Political Morality

The great intellectual challenge is to develop the conceptual means to reinterpret the formidable problems that prevent realization of an authentic justice in Africa. Bell (1995:39) notes that a spiritual vacuum is created by the so-called absence of values. A number of people, especially most African leaders have lost even a minimum sense of social justice and ethical 
character. Hence, the process of debasement of many African societies has set in, and there is anomie and also a loss of personal, moral and social respect and integrity. According to Care (1978:316), acceptable policies must reflect and respond to the interests of members of the community. The interests of the members of community make sense only in the context of the recognition of their rights. Goodin (1981:92) holds that citizenship is man's basic right, for it is nothing less than the right to have rights. Remove this priceless possession and he has no lawful claim to protection from any nation and no nation may assert rights on his behalf.

Apart from the idea of law and rights as core imperatives of the restoration of the humanity of Africans, there is also the question of consensus as a basis for justice. According to Blondel (1966:133), every society requires some kind of consensus, if it is to remain viable and orderly: there is a limit to the degree of tension a society can tolerate without breakdown. Some kind of consensus is central to the idea of political morality and justice, since, as Bramson (1966:194) says, human beings with different kinds of formative experiences often tend to perceive the same thing differently. Members of the same society as well as members of different societies will often develop radically different visions of the good society. The value of dialogue is an example of an important condition that can allow individuals and groups to act responsibly and intelligently.

Dialogue is vital not just because it is cherished as a value that has intrinsic worth, but that it leads to positive impacts on human personal and social life as it creates trust. Fukuyama (1999:85-90) argues that trust is central to the "character of the moral relationships that exist between individuals in the broader society". Trust can be cultivated through the practice of shared norms and values that bind groups together, leading to a stronger community. Trust elicits the virtues of sincerity, reliability and reciprocity in individuals through the application of moral rues. If we are to create a social arena where trust and justice will prevail, then there is a need for dialogue. Dewey (1966:4-5) holds that dialogue is essential to human existence because, "men live in a community in virtue of the things which they have in common and communication, or the way in which they come to possess things in common". When dialogue has been institutionalised, there will be greater opportunity for just and fair legitimate human interaction that is founded on the belief in shared experiences. The creation of the awareness of national consciousness will be the outcome of a system that appreciates the conduct of interpersonal relations in an atmosphere that cherishes the fair recognition of the worth, and contribution, of each person to the community's pool of such goods.

The development of the disposition to engage in dialogue will ensure the sharing of information and negotiation of claims on the basis of just and humane principles. To this effect, 
dialogue aims at mitigating those feelings of isolation, frustration, injustice and oppression that individuals retain in a political society. Such feelings may arise out of competitions for resources and influence, as well as the shortfalls in the operations of the systems of justice within the society. Sebagereka (1993:76) holds that dialogue implies the acceptance of pluralism, and the need for tolerance and respect for the views of others. It recognises the diversity views, the force of superior argument, and the possibility of alternative approaches to the resolution of differences. Dialogue is important in a democracy in so far as it permits individuals or representatives of these groups to co-jointly negotiate the basis of their conception of the common good. It also ensures the clarity of the rules governing social existence and the exercise of public power. Dialogue reinforces the rule of justice by seeking a common understanding of ends, and the nature of social goods that are to be determined using patterns of social relationships based on negotiation. This point is supported by Habermas (1999:154) who says that justice consists in permitting or encouraging persons (human or artificial) to participate freely and equally in conversations aimed at arriving at, or reaching consensus on rules and norms regulating their conduct. How then do these norms and values have concrete effects on the democratic society? The concern for justice and dialogue as its instrument is the struggle to define the political status conferred on individuals by civilized societies as embodied in a set of values and obligations. However, problems arise when the state dictates certain values and obligations to the citizens without fulfilling the reciprocal obligations for the citizen's welfare and security. A necessary and important element of justice is not just dialogue, but also, a conception of citizenship underwritten by the respect for the law and the display of civilized behaviour (Thimmaiah, 1988:66).

\section{Citizenship as a Key Instrument of Restoring Justice in Africa}

Justice makes little sense outside of the rules and conventions that can assure civilised conduct. Civility and civilised ways of living are necessary corollaries of a de-ethnicisation process that vitiates corruptive, obstreperous primordial affinities. So also there is a need for a decolonisation process that erodes a manipulative, perverted political class structures that have brought little good to Africans. To ensure justice, the idea of citizenship can be valuable as one of the notions capable of restoring the integrity of peoples in the modern African societies. Sullivan (1994:200) holds that the citizen must develop civic virtues, which set as a kind of minimum standard of competence for political participation the ability to observe the common rules and laws and to understand how these are arrived at and changed by reference to the 
notion of the common good. This fact further raises questions about problems in the reconciliation of human actions and the construction of a society. Habermas (1996:101-103) says that citizenship is based on an act of association through which isolated and success in oriented individuals transform themselves into citizens oriented to the common good of an ethical community. The basic problem of value orientation in citizenship focusing on how to mediate the quest for the common good and the differentiated interest positions of private persons.

Habermas (1996:493) holds that citizenship is linked to national consciousness viewed as a specific manifestation of cultural integration. Habermas (1996:495) says that the nation of citizens finds its identity not in ethnic and cultural commonalities but in the practice of citizens who actually exercise their rights to participation and communication. Held (1989:182) says that the rights of citizens must be both formal and concrete, holding that hold that citizens should have the actual capacity (the health and resources) to take advantage of opportunities before them (1989:184). Held (1989:190) says that citizenship implies full membership of a community where membership entails participation by individuals in the determination of the conditions of their own association. Held (1989:199) says that citizenship implies a putative reciprocity of rights against, and duties towards the community. Citizenship is about involvement of people in the community in which they live. Rawls (1996:188) suggests that we can understand the idea of citizenship in a society when we examine its basics structures. By this structure, we mean such a society's main political, social and economic institutions, and how they fit together into one unified system of social co-operation. Dworkin (1996:207) holds that we are in need of the idea of an integrated citizen who recognizes that his own well being is derived from the community's well-being and must be concerned with the community's overall health. Dworkin (1996:217) notes that citizens identify with their political community when they recognize that the community has a communal life and that the success or failure of their own life is ethically dependent on the success or failure of that communal life. $\mathrm{He}$ (1996:219)also holds that an integrated citizen accepts that the value of his own life depends on the success of his community treating every one with equal concern. If every one understands that everyone else shares that attitude, then the community will have an important source of stability and legitimacy.

Sullivan (1994:190-191) holds that citizenship in democratic society is marked by impersonal relationships of mutual care and respect and a dedication to the institutions and customs supporting their common life. We are in need of an idea of citizenship that promotes personal self-development. Mutual interdependency is the foundational notion of citizenship 
the basic psychological dynamic of the participants in this interdependent way of life is to respond and to care. The citizen comes to know who she is by understanding the web of social relationships surrounding her. If the above is accepted, then we must agree with Koch (1958:166) who holds that "political issues today literally force us to deal with values. Professional philosophers in the twentieth $\left(20^{\text {th }}\right)$ century have indeed manifested a great interest in the exploration and, critique or reconstruction of value theory". Harris (1957:1) says "the social cooperation and coordination of human activities which is the essence of civilised life, is not possible without regulation." Waldron (1988:732) notes that there are some moral and religious commitments that cannot be pursed individualistically, but only by people acting together as a society. It is issues such as the above that take us into the discourse on democratic norms. There is a need to conceptually examine the nexus between national consciousness, democratic norms and political community.

Feinberg (1966:137) points out that we have duties, which we owe to people and society. Such duties are obligations. As citizens we have rights of community membership or positive rights, which as Feinberg (1966:140) points out must be recognised because they mould a society into a cohesive community. These are duties of care that every citizen is said to owe to any and every person in a position to be injured by his negligence. There is also the duty that every citizen has to come to the aid of accident victims. Thus, Wright (1998:144) holds that it is difficult to see how the critical questions and challenges concerning Africa's future can be tackled without the active participation of all its citizens. Nyerere (1987:479) rightly holds that in any human society compromise between individuals in not only necessary but desirable. For, it is the only means of arriving at the common denominator that makes society possible. Compromise is desirable due to the quest for the common good or issues in the good of the whole society.

Also, Barnard (1983:236) avers that to become citizens, people had first to become members: instead of being independent entities they had to become interdependent parts within a larger whole. Barnard (1983:246-247) makes it clear that even though agreement and unity are valued and valuable yet we must not sacrifice diversity. While both consensus and cooperation presuppose some common understanding of what would be done and not done cooperation unlike consensus does not aim at the elimination of divergences but merely at avoiding the disruption of the societal whole. Thus, Oliver (1960:283-284) says that only a theory of the solidarity of interests of all members of society shows how society is possible. Even the bottom social classes are much better off than they would be in the absence of social cooperation. Gould $(1980: 717,723)$ formulates this demand in terms of a theory of social 
ontology, which concerns the nature of the entities, relations and processes that compose social life. In this idea of social ontology the individuals who are capable of self-realisation are understood as agents whose activity is characterised fundamentally by free choice and who seek to fulfill purposes through social relations and joint actions.

Battisti (1983:42) reiterates that there are established laws for the continuous reproduction of and distribution of those goods, which are necessary to satisfy the needs of a socialised society. These laws constitute the moral and political structures of the society and stimulate the work and interests of different individuals to cooperate for the common wellbeing. They dictate the rules concerning distributive justice, decide which forces should insure society's defence and should build up public revenue in order to finance those expenses, which are required by the safety, the good order and the prosperity of the state. Ingham (1990:87) notes that the basic problem is to find institutional means of to enable ethnic groups to live together in some degree of equity and mutual security and to find means of controlling the lust for power and wealth. Nduka (1977:347-348) postulates the framework for the logical of distributive justice in which there must be a re-examination of the historical, economic, ideological and other foundations of our habits of distribution - habits that profoundly affect the character of any society.

\section{A Merit-Based Reward System as a Basis for Justice in Africa}

The whole question of the mechanisms for pursuing the realisation of justice in Africa is dependent on the amalgamation of a combination of values and institutions. The most notable that we have chosen to discuss are the role of the constitution, leadership, interest groups, formal and informal agents of legal and legitimate socialisation and association. We are especially inclined to discerning their core tasks and focus as pursuing all known formal and informal means of establishing and sustaining machineries for power acquisition and transfer, effective and productive social dialogue, definition and guarantee of viable citizenship and the installation of machineries of desert and merit-based individual and distributive justice. These tasks call for the creation of new approaches to the management of the African realities, as well as the construction of new levels of aspirations for all stakeholders. This is simply the demand for attitude change, which depends on reviewing the scope and attractiveness of the reward system and the credibility that goes with the new vision of justice and development in Africa.

There is a need for merit in the affairs of a people and society. This is the more significant in the context of Africa that is bedeviled by all sorts of persons and institutions 
making undeserved and unmerited claims on others, due to factors such as ethnicity, corruption, ineptitude, influence, ignorance, among others as Pojman (1997:557-558) points out that "we also speak of merit as focusing on the actual outcome of or contribution of actions. Rewarding good works encourages further good works and punishment deters bad actions. By recognising and rewarding merit, we promote efficiency and welfare." Daniels (1978:207) makes a similar point when he insists that merit is basically "ability plus effort. Claims of merit are derived from considerations of efficiency or productivity."

For justice to prevail in Africa, there is a need for reviewing our reward system such that incentives for meritorious acts of excellence, diligence and good conduct will be nationalised and institutionalised. These tasks can start with the demarcation of the scope of rewards for merit within core institutions. These rewards can take the form of providing commendations, incentives, opportunities and awards in cash or kind. This will ensure the mitigation of ethnicity and nepotism. As Young (1994:88) puts it so directly, "nepotism should go, bribery should go, inheritance should go as means of attaining public office, the belief has become established that it is wrong to allow nepotism, bribery, or inheritance any sway: individual merit should be the only test that should apply."

\section{Conclusion}

Our study has examined the problem of creating societies where justice will be a reality for all. It offered reasons for the deterioration into spectral and pervasive corruption, ineptness, authoritarianism, human rights violations, tribalistic exclusiveness, which have ensured the erosion of justice and security. We saw that the endemic susceptibility of African social and political life to injustices and perversions was due to the absence of a proper idea of justice that can underwrite the internal consistency and wider social political consequences of the developmental institutions and processes in much of Africa. We saw the need for erecting core normative, ethical and phenomenological presuppositions that can foster certain developmentally suitable values and attitudes. However, the attainment of this end necessitated the postulation of a new approach to justice for viable social order and holistic development. The aim of the study was to pursue a more systematic and holistic way of creating and institutionalising the principles and values that can ensure enduring and viable justice that can in turn positively affect the redirection of African development towards security, morality, peace and well being. This, for us, was seen as a normative and empirical engagement with core African institutional and cultural values. 


\section{References}

Barnard, F.M. (1983) "National Culture and Political Legitimacy: Herder and Rousseau" Journal of the History of Idea. Vol. xliv, No. 2. (April-June) Pp.231-253.

Battisti, Guiseppa (1983) “Changing Metaphors of Political Structures" Journal of the History of Ideas Col. xliv, No. 1 (January-March) Pp. 31-54

Bell, Daniel (1995) “The Communitarian Critique of Authoritarianism” Society (July/August) Pp. 38-43.

Blondel, Jean (1966) "Government" in Normal Mackenzie (Ed) A Guide To The Social Sciences (London: Weindenfield \& Nicolson) Pp. 119-148

Bramson, Leon (1966) "Social Theory" in Norman Mackenzie (Ed) A Guide to the Social Sciences (London: Weidenfield \& Nicolson) Pp. 185-203

Brugger, W, (1972) Philosophical Dictionary (Trans) Baker K. (Washington: Gonzaga University Press).

Burns, James Macgregor (1981) "Power and Politics” Society. (May/ June). Pp. 5-9.

Care, Norman S. (1978) "Participation and policy” Ethics. Volume, 88. No. 4, (July).

Carr, Craig L. (1981), “The concept of formal justice” Philosophical Studies.vol.39. pp. 211-226.

Crocker, David. (1991) “Towards Development Ethics” World Development Vol. No.5 Pp. 457483.

Daniels, Norman., (1978) "merit and meritocracy" Philosophy and Public affairs. Vol.7.no.3. (Spring). Pp. 206-223.

Dewey, John (1966) Democracy and Education. (New York: The Free Press). P. 4-5

Dworkin, Ronald (1996) "Liberal Community" In Shlomo Avineri and Avner De-Shalit (Eds) Communitarianism and Individualism (Oxford: Oxford University Press) Pp. 205-224.

Ehman, Robert., (1980)., Rawls and Nozick: Justice without well-being” the journal of value inquiry. Vol.14. no. 1. (Spring). Pp. 7-21.

Eshete, Andreas (1975)., "Contractarianism and the scope of justice” Ethics. Vol. 85. pp. 38-49. Feinberg, Joel (1966) "Duties, Rights and Claims" American Philosophical Quarterly Vol. 3, No. 2. (April) $137-144$.

Fox, Russell (2000) Justice in the Twenty-First Century. London: Cavendish Publishing Company. Fried, Charles (1964)., "Natural law and the concept of justice" ethics vol. lxxiv. no. 4. (July). pp. 237-254.

Fukuyama, Francis (1999) The Great Disruption (London: Profile Books). 
Glazer, Nathan (1981) “Trends in Social Justice” Dialogue. Number 52. vol.2. pp.13-17.

Goldstein Joshua (1999) International Relations $3^{\text {rd }}$ edition (New York. Longman Addison Wesley)

Goodin, Robert E. (1981) “The Political Theories of Choice and Dignity” American Philosophical Quarterly. Vol. 18. No. 2. (April) Pp. 91-100

Gould, Carol. C. (1980) "Contemporary Legal conceptions of Property and Their Implications for Democracy" The Journal of Philosophy Vol. Lxxvii, No. 11. (November) Pp. 716-729.

Grondona, Mariano (2000) ., "a cultural typology of economic development” in Lawrence E.

Harrison and Samuel P. Huntington (eds) Culture Matters. New York Basic books. Pp.44-55.

Gyekye, Kwame (1997) Tradition and Modernity: Philosophical Reflections on the African Experience (New York: Oxford University Press)

Habermas, Jurgen (1999) Between Facts and Norms (Trans) William Rehg (Massachusetts: The MIT Press).

Haring, Bernard (1979) Free and Faithful in Christ Volume 2. (Middle Green: St. Paul Publications). Harris, Errol (1957) "Political Power” Ethics. Vol. Lxviii. No. 1. (October) Pp. 1-10

Harrison, Lawrence E., (2000), "Promoting Progressive cultural change" in Lawrence E. Harrison and Samuel P. Huntington (eds) Culture Matters. New York: Basic books. Pp.296-307. Held, David (1989) Political theory and the Modern State (California: Stanford University Press) Hospers, John (1976) An Introduction To Philosophical Analysis (London: Routledge and Kegan Paul).

Ingham, Kenneth (1990) Politics in Modern Africa: The Uneven tribal dimension (London: Routledge) Johann, Robert (1966) "Love and Justice" In De George (Ed) Ethics and Society (New York: Anchor)

John Paul II (1981) Laborem Exercens Encyclical On Human Work (London Catholic Truth Society).

Koch, Adrienne (1958) “The Status of Values and Democratic Theory” Ethics Vol. Lxviii No. 3 (April). Pp. 166-185

Kymlicka, Will (1999) Multicultural Citizerenship (Oxford Clarendon Press)

Lasswell, Harold D., (1956), "Power and Personality" in Heinz Eulau, Samuel J. Eldersveld \& Morris Janowitz (edited) Political Behaviour: A Reader in Theory and Research. Illinois: The free Press. pp. 90-103.

Litke, Robert. F. (1992) “violence and power” International Journal Of The Social Sciences. No. 132. pp. 173-183.

Mackenzie, J. S., (1963), Outlines Of Social Philosophy London: George Allen \& Unwin. Mbiti, John. S., (1969), African Religions And Philosophy London: Heinemann. 
Mill, J.S (1990) On Liberty Representative Government Utilitarianism Great Books of The Western World, Vol. 40 (Edited) M.J Alder (Chicago: Encyclopedia Britannica Inc).

Morgenthau, Hans J. (1974) “Justice and Power” Social Research. Vol.4. no. 1. (Spring). Pp. 163175.

Nduka, Otonti (1977) “The Rationality of the Rich In Nigeria” In Peter Gutkind and Peter Waterman (Eds) African Social Studies: A Radical Reader. (London: Heinemann). Pp. 343-350.

Neuner, J. and Dupuis, J. (1990) The Christian Faith $5^{\text {th }}$ Edition Edited (New York: Alb House). Nielsen, Kai (1996) "Conceptions of Justice" In Mary Hawkesworth (Ed) Encyclopedia of Government and Politics Volume 1 (London: Routledge).

Nyerere, Julius (1987) “Democracy and The Party System" In Cyrus Mutiso \& S.W. Rohio (Eds) Readings in African Political Thought (London: Heinemann) Pp. 478-481

Oliver, Henry. M. (1960) "Von Mises on The Harmony of Interests" Ethics Vol. Lxx, No. 4. (July) Pp. 282-290.

Partridge, P.H., (1963) "Politics and Power" Philosophy. Vol. Xxxviii. No.144. (April). Pp. 117135.

Pazhayampallil, Thomas (1995) Pastoral Guide (India: Kristu Jyoti Publications).

Peperzak, Adrian (1971) "Freedom" in International Philosophical Quarterly Vol. Xi, No. 3 (September).

Pham, Peter (2005) "Legitimacy, Justice, and the Future of Africa" Human Rights and Human Welfare. Vol.5. 31-49.

Pojman, Louis (1997) “Equality and Desert” In Philosophy Vol. 72. No. 282 (October). Pp.549570 .

Pritchard, Michael (1979) "On understanding political power" The Journal Of Value Inquiry. Vol.xiii. no.1. (Spring). 21-31.

Rawls, John (1996) "Justice As Fairness: Political Not Metaphysical” In Shlomo Avineri and Avner de-Shalit (Eds) Communitarianism and Individualism (Oxford: Oxford University Press) Pp. 186-204.

Said, Abdul Aziz (1977) "Pursuing Human Dignity” Society (November/December) pp. 34-38. Samatar, Abdi Ismail and Samatar, Ahmed .I. (2002) The African State ((eds) (Portsmouth: Heinemann)

Scott, William (1992) "Review essay: Democracy and Moral Development" Society. (November/ December). Pp.119-123.

Sebagereka, Victoria (1993) "The Ongoing Transition To Democracy in Africa and The Role Women Must Play in The Sustainment of Democracy: The Ugandan Experience" Africa 
Leadership Forum Sustainment of Democratization and Good Governance in Africa (Ibadan: Africa Leadership Forum Intec).

Soyinka, Wole (2004) A Climate OfFear. Lecture 2: Power and Freedom. Reith Lecture Series. Web resource. www.bbc.co.uk/radio4/reith2004/.

St. Aquinas. (1990) The Summa Theological Aquinas II (Trans) F. Shapcote. L. Great Books OfThe Western World Vol. 18 (Edited) Alder M.J. (Chicago Encyclopaedia Britannica Inc).

Sullivan, William .M. (1994) “A Renewal of Civic Philosophy” In Markate Daly (Ed) Communitarianism A New Public Ethics (California: Wadsworth) Pp. 190 - 202.

Thimmaiah, G. (1988) "Behavioural and Attitudinal Norms of Citizens" in D.N. Saxena (Ed) Citizenship Development and Fundamental Duties (New Delhi: Citizenship Development Society). Pp. 65-90.

Waldron, Jeremy (1988) ‘The Philosophy of Rights’ In G.H.R. Parkinson (Ed) An Encyclopedia of Philosophy (London: Routledge). Pp. 713-735.

Werhahn, P. H. (1990) 'The Entrepreneur ORDO SOCIALIS No. 4 German AACSS

Whitman, Jim (2002) "Global Governance as the Friendly Face of Unaccountable Power" Security Dialogue Vol.33. no.1. Pp.45-57.

Wright, Stephen (1998) "Africa and Global Society: Marginality, Conditionality and Conjecture" In Sola Akinrinade and Amadu Sesay (Eds) Africa In the post Cold War International System. (London: Cassell Pinter) Pp. 133-146.

Young, Iris Marion (1990) Justice and the Politics of Difference (New Jersey Princeton University Press).

Young, Michael (1994) “Meritocracy Revisited” Society. (September/ October). Pp.87-89.

Universidade Católica de Petrópolis

Centro de Teologia e Humanidades

Rua Benjamin Constant, 213 - Centro - Petrópolis

Tel: (24) 2244-4000

lexhumana@ucp.br

http://seer.ucp.br/seer/index.php?journal=LexHumana

UJOMU, Philip Ogo; OLATUNJI, Felix. PHILOSOPHICAL REFLECTIONS ON SOCIAL JUSTICE AND SOCIAL ORDER IN POST-COLONIAL AFRICA. Lex Humana, http://seer.ucp.br/seer/index.php/LexHumana , v. 5, n. 2, p. p. 130-153, jul/dec. 2013. ISSN 2175-0947. Disponível em: http://seer.ucp.br/seer/index.php?journal= LexHumana\&page $=$ article\&op $=$ view\&path $\% 5 \mathrm{~B} \% 5 \mathrm{D}=395$. Acesso em: 18 de dezembro 2013. 